\title{
Penegakan Hukum Pidana Terhadap Penyelundupan Baby Lobster
}

\author{
Ayu Veronica, Kabib Nawawi, Erwin \\ Fakultas Hukum, Universitas Jambi \\ Author's Email Correspondence: ayuvrnc1112@gmail.com
}

\begin{abstract}
ABSTRAK
Tujuan artikel ini adalah untuk mengetahui penegakan hukum Hukum Pidana Terhadap Penyelundupan Baby Lobster di Wilayah Hukum Polres Tanjung Jabung Timur serta kendala dalam penegakan hukum Hukum Pidana tersebut?. Dengan menggunakan metode yuridis empiris, artikel ini menunjukkan penegakan hukum pidana Penyelundupan Baby Lobster di Wilayah Hukum Polres Tanjung Jabung Timur belum terlaksana dengan efektif karena keterpaduan dan koordinasi antar aparat penegakan hukum serta partisipasi masyarakat untuk ikut berperan dalam pelaksanaan penegakan hukum masih kurang, penegakan hukum akan berjalan dengan efektif apabila aparat penegak hukum dapat bekerja sama secara profesional dalam menegakan hukum. Kendala dalam penegakan hukum pidana penyelundupan Baby Lobster di Wilayah Hukum Polres Tanjung Jabung Timur terhadap pelaku, antara lain pada faktor sarana dan prasaranannya dan sumber daya manusia personil penyidik yang kurang banyak, dana yang terbatas dan faktor kurangnya kesadaran hukum masyarakat.
\end{abstract}

\section{ARTICLE HISTORY}

Submission: 2020-11-21

Accepted: 2020-12-02

Publish: 2020-12-02

KEYWORDS: Baby Lobster; criminal law; enforcement, smuggling.

\begin{abstract}
The purpose of this article is to find out the enforcement of the Criminal Law Against the Smuggling of Baby Lobster in the Legal Area of the Tanjung Jabung Timur Police and the obstacles in enforcing the Criminal Law. Using the empirical juridical method, this article shows that the criminal law enforcement of Baby Lobster Smuggling in the Legal Area of the Tanjung Jabung Timur Police has not been implemented effectively because of the integration and coordination between law enforcement officials and community participation to play a role in law enforcement is still lacking, law enforcement will run effectively if law enforcement officers can cooperate professionally in enforcing the law. Constraints in enforcing the criminal law of smuggling baby lobster in the Legal Area of the Tanjung Jabung Timur Police against the perpetrators, among others, are the factors of facilities and infrastructure and insufficient human resources of investigators, limited funds and the lack of public legal awareness.
\end{abstract}

\section{A. PENDAHULUAN}

Perikanan mempunyai peranan yang penting dan strategis dalam pembangunan perekonomian nasional, terutama dalam meningkatkan perluasan kesempatan kerja, pemerataan pendapatan, dan peningkatan taraf hidup bangsa pada umumnya, nelayan kecil, pembudi daya-ikan kecil, dan pihak-pihak pelaku usaha di bidang perikanan dengan tetap memelihara lingkungan, kelestarian, dan ketersediaan sumber daya ikan.

Untuk menjamin terselenggaranya pengelolaan sumber daya ikan secara optimal dan berkelanjutan perlu ditingkatkan peranan pengawas perikanan dan peran serta 
masyarakat dalam upaya pengawasan di bidang perikanan secara berdaya guna dan berhasil guna. Pelaksanaan penegakan hukum di bidang perikanan menjadi sangat penting dan strategis dalam rangka menunjang pembangunan perikanan secara terkendali dan sesuai dengan asas pengelolaan perikanan, sehingga pembangunan perikanan dapat berjalan secara berkelanjutan. Oleh karena itu, adanya kepastian hukum merupakan suatu kondisi yang mutlak diperlukan. Dalam Undang-Undang ini lebih memberikan kejelasan dan kepastian hukum terhadap penegakan hukum atas tindak pidana di bidang perikanan, yang mencakup penyidikan, penuntutan, dan pemeriksaan di sidang pengadilan, dengan demikian perlu diatur secara khusus mengenai kewenangan penyidik, penuntut umum, dan hakim dalam menangani tindak pidana di bidang perikanan. Peranan aparat penegak hukum dalam proses penegakan hukum sangat menentukan arah dan tujuan serta hasil yang akan dicapai dalam penegakan hukum itu sendiri. ${ }^{1}$

Sistem penegakan hukum yang mempunyai nilai-nilai yang baik adalah menyangkut penyerasian antara nilai dengan kaidah serta dengan perilaku nyata manusia. Pada hakikatnya, hukum mempunyai kepentingan untuk menjamin kehidupan sosial masyarakat, karena hukum dan masyarakat terdapat suatu interelasi.

Fungsi penegakan hukum adalah untuk mengaktualisasikan aturan-aturan hukum agar sesuai dengan apa yang dicita-citakan oleh hukum itu sendiri, yaitu mewujudkan sikap atau tingkah laku manusia sesuai dengan yang telah diterapkan oleh suatu undang-undang atau hukum. Penegakan hukum pada hakekatnya merupakan penegakan ide-ide atau konsep-konsep serta usaha untuk mewujudkan ide-ide dari harapan masyarakat untuk menjadi kenyataan.

Penegakan hukum merupakan bagian dari usaha suatu bangsa untuk mempertahankan eksistensinya melalui perorganisasian sumber daya guna merealisasikan cita-cita dan citra masyarakat yang terkandung dalam tata hukumnya. ${ }^{2}$

Pengertian penegakan hukum antara lain sebagaimana yang dikemukakan oleh Soerjono Soekanto, bahwa:

Secara konsepsional, inti dari penegakan hukum terletak pada kegiatan menyelaraskan hubungan nilai-nilai yang terjabarkan di dalam kaedah-kaedah yang mantap dan mengejawantah dan sikap tindak sebagai rangkaian penjabaran nilai tahap akhir, untuk menciptakan, memlihara dan mempertahankan kedamaian pergaulan hidup. ${ }^{3}$

Pendapat lain mengenai penegakan hukum menurut Sudikno Mertokusumo, bahwa:

Hukum berfungsi sebagai perlindungan kepentingan manusia. Agar kepentingan manusia terlindungi, hukum harus dilaksanakan. Pelaksanaan hukum dapat berlangsung secara normal, damai, tetapi dapat terjadi juga karena pelanggaran hukum. Dalam hal ini hukum yang telah dilanggar itu harus ditegakkan, melalui penegakan hukum inilah hukum menjadi kenyataan. Dalam penegakan hukum ada tiga unsur yang selalu harus diperhatikan, yaitu kepastian hukum,

1 Monika Dwi Putri Nababan,Kabib Nawawi."Pelaksanaan Hak Tahanan (Tantangan dan Permasalahan). PAMPAS: Journal of Criminal Law, Volume 1, No. 1 (2020), hlm. 82. https://online-journal.unja.ac.id/Pampas/article/view

2 M. Yasin Al arif, "Penegakan Hukum Dalam Perspektif Hukum Progresif", Undang Jurnal Hukum, Vol. 2, No. 1 (2019), hlm. 1https://ujh.unja.ac.id/index.php/home/article/view/66

3 Soerjono Soekanto, Faktor-Faktor yang Mempengaruhi Penegakan Hukum (Jakarta: Raja Grafindo Persada, 1983), hlm. 5. 
(Rechtssichhherheit), kamanfaatan (Zweckmaasigheit) dan keadilan (Gereichtigheit). ${ }^{4}$

Selanjutnya, Selo Sumardjan seperti dikutip Sidik Sunaryo mengemukakan bahwa: "Penegakan hukum berkaitan erat dengan usaha menanamkan hukum di dalam amsyarakat yang didasarkan pada sistem nilai-nilai yang berlaku dan jangka waktu menanamkan hukum". ${ }^{5}$

Penegakan hukum itu harus bereformasi, baik dari segi penegak hukum itu sendiri, struktur hukum, dan substansi hukum yang harus memiliki kebijakan sesuai perkembangan zaman. Penegakan hukum berlaku untuk semua jenis tindak pidana, mulai dari tindak pidana yang terberat hingga tindak pidana yang teringan.

Hukum memiliki peranan yang sangat penting dalam kehidupan bermasyarakat, karena hukum bukan hanya menjadi parameter untuk keadilan, keteraturan, ketentraman dan ketertiban, tetapi juga untuk menjamin adanya kepastian hukum. Pada tataran selanjutnya, hukum semakin diarahkan sebagai sarana kemajuan dan kesejahteraan masyarakat. ${ }^{6}$

Menurut Satjipto Raharjo, bahwa:

Keinginan dan kesadaran tiap-tiap individu di dalam masyarakat menjadi dasar dibentuknya hukum, dengan maksud agar hukum tersebut dapat berjalan sebagaimana dicita-citakan oleh masyarakat itu sendiri, yakni menghendaki kerukunan dan perdamaian dalam pergaulan hidup bersama. Orang yang melakukan tindak pidana akan mempertanggung jawabkan perbuatan tersebut dengan pidana apabila ia mempunyai kesalahan, seseorang mempunyai kesalahan apabila pada waktu melakukan perbuatan dilihat dari segi masyarakat menunjukan pandangan normatif mengenai kesalahan yang dilakukannya. ${ }^{7}$

Penegakan hukum meliputi dua hal, yaitu: (1) upaya hukumyang ditujukan untuk mencegah dan menanggulangi pelanggaran melalui pendayagunaan kewenangan sesuai dengan mandat yang diberikan peraturan perundang-undangan; (2) court review terhadap putusan pengadilan.

Soerjono Soekanto menjelaskan bahwa masalah pokok dari pada penegakan hukum sebenarnya terletak dari pada faktor-faktor yang mungkin mempengaruhinya. Faktor-faktor itu mempunyai arti yang netral sehingga dampak positif atau negatifnya terletak pada isi faktor-faktor tersebut. Faktor-faktor tersebut adalah sebagai berikut:

1. Faktor hukumnya sendiri

2. Faktor penegak hukum, yakni pihak-pihak yang membentuk maupun yang menerapkan hukum

3. Faktor sarana atau fasilitas yang mendukung penegakan hukum

4. Faktor masyarakat yakni lingkungan dimana hukum tersebut berlaku atau diterapkan

4 Sudikno Mertokusumo, Mengenal Hukum Suatu Pengantar (Yogyakarta: Liberty, 2007), hlm. 160.

5 Sidik Sunaryo, Sistem Peradilan Pidana (Malang: Universitas Muhammadiyah Malang, 2004), hlm. 56.

6 Andi Hamzah, Bunga Rampai Hukum Pidana dan Acara Pidana (Jakarta: Ghalia Indonesia, 2001), hlm. 14.

7 Satjipto Rahardjo, Bunga Rampai Permasalahan dalam Sistem Peradilan Pidana, Pusat Pelayanan Keadilan dan Pengabdian Hukum (Jakarta: Pusat Pelayanan Keadilan dan Pengabdian Hukum, 1998), hlm. 11 
5. Faktor kebudayaan yakni sebagai hasil karya, cipta dan rasa yang didasarkan pada karsa manusia di dalam pergaulan hidup. ${ }^{8}$

"Tindak pidana merupakan perbuatan melawan hukum yang dilakukan oleh seseorang dan patut dipidana sesuai dengan kesalahannya sebagaimana dirumuskan dalam undang-undang. Orang yang melakukan perbuatan pidana akan mempertanggungjawabkan perbuatan tersebut dengan pidana apabila ia mempunyai kesalahan, (penyelundupan)". ${ }^{9}$

Penyelundupan Baby Lobster melalui Kementerian Kelautan dan Perikanan memberlakukan Peraturan Menteri Kelautan dan Perikanan Nomor 56/PermenKP/2016 tentang Larangan Penangkapan dan/atau Pengeluaran Lobster (Panulirus Spp.), Kepiting (Scylla Spp.), dan Rajungan (Portunus Spp.) dari Wilayah Negara Republik Indonesia.

Pasal 2 Peraturan tersebut menyebutkan penangkapan dan/atau pengeluaran Lobster (Panulirus spp.), dengan Harmonized System Code 0306.21.10.00 atau 0306.21.20.00, dari wilayah Negara Republik Indonesia hanya dapat dilakukan dengan ketentuan: a) tidak dalam kondisi bertelur; dan b) ukuran panjang karapas di atas 8 (delapan) $\mathrm{cm}$ atau berat di atas 200 (dua ratus) gram/ekor.

Selanjutnya Pasal 7 Ayat (3) menjelaskan bahwa: "setiap orang yang mengeluarkan Lobster (Panulirus spp.), dalam kondisi yang tidak sesuai dengan ketentuan sebagaimana dimaksud dalam Pasal 2 dikenakan sanksi sesuai ketentuan peraturan perundang-undangan.

Penyelundupan Baby Lobster merupakan suatu tindak pidana sebagaimana diatur dalam Undang-Undang Nomor 31 Tahun 2004 sebagaimana telah diubah dengan Undang-Undang 45 Tahun 2009 tentang Perikanan, dalam Pasal 88 disebutkan bahwa:

Setiap orang yang dengan sengaja memasukkan, mengeluarkan, mengadakan, mengedarkan, dan/atau memelihara ikan yang merugikan masyarakat, pembudidayaan ikan, sumber daya ikan, dan/atau lingkungan sumber daya ikan ke dalam dan/atau ke luar wilayah pengelolaan perikanan Repbulik Indonesia dipidana dengan pidana penjara paling lama 6 (enam) tahun dan denda paling banyak Rp 1.500.000.000,- (satu milyar lima ratus juta rupiah).

Untuk melakukan penanggulangan tindak pidana penyelundupan baby lobster merupakan bagian dari proses penegakan hukum yang harus dilakukan oleh aparat penegak hukum. Penegakan hukum secara ideal akan dapat mengantisipasi berbagai penyelewengan pada anggota masyarakat dan adanya pegangan yang pasti bagi masyarakat dalam menaati dan melaksanakan hukum.

Kasus tindak pidana penyulundupan baby lobster di wilayah hukum Polres Tanjung Jabung Timur dapat dilihat pada tabel berikut:

Soerjono Soekanto, Faktor-Faktor yang Mempengaruhi Penegakan Hukum (Jakarta: Rajawali, 1983), hlm. 5.

9 Andi Hamzah, Bunga Rampai Hukum Pidana, hlm. 17 
Tabel. 1

Data Penyelundupan Baby Lobster di Wilayah Hukum Polres

Tanjung Jabung Timur

\begin{tabular}{ccccc}
\hline Tahun & Jumlah & \multicolumn{3}{c}{ Proses Hukum } \\
\cline { 3 - 5 } & & Penyidikan & Kejaksaan & Pengadilan \\
\hline 2018 & 2 & 2 & 2 & 1 \\
2019 & 1 & 1 & 1 & 1 \\
\hline & 3 & 3 & 3 & 2
\end{tabular}

Sumber data: Polresta Tanjung Jabung Timur

Dari data tersebut bahwa kasus penyelundupan baby lobster di wilayah hukum Polres Tanjung Jabung Timur jumlah kasus selama 2 (dua) tahun yaitu 3 kasus, 2 (dua) kasus yang telah diputuskan oleh Pengadilan Negeri Tanjung Jabung Timur yaitu 1 (satu) kasus tahun 2019 dan 1 (satu) kasus pada tahun 2018, sedangkan 1 (satu) kasus pada tahun 2018 tidak dilanjutkan ke Pengadilan karena sudah dihentikan (SP3) karena tidak lengkap alat bukti, 2 (dua) kasus yang sudah mendapat kepastian hukum dengan putusan Nomor 6/Pid.Sus/2019/PN. Tjt, dan Putusan Nomor 12/Pid.Sus/2018/PN. Tjt. Jaksa Penuntut Umum mendakwa dengan dakwaan:

1. Putusan Nomor 6/Pid.Sus/2019/PN. Tjt

Terdakwa atas nama Abdul Rahman Bin Ambok Riuk dan Mulyadi Als Mulia Bin Samsu terbukti secara sah dan meyakinkan bersalah melakukan tindak pidana secara bersama-sama dengan sengaja memasukkan, mengeluarkan, mengadakan, mengedarkan dan/atau memelihara ikan, yang merugikan masyarakat, pembudidayaan ikan, sumber daya ikan, dan/atau lingkungan sumber daya ikan ke dalam dan/atau keluar wilayah pengelolaan perikanan Republik Indonesia" melanggar Pasal 16 Ayat (1) Jo Pasal 88 UU RI No. 31 Tahun 2004 tentang Perikanan sebagaimana telah diubah dengan UU RI No. 45 Tahun 2009 tentang Perikanan Jo Pasal 55 Ayat (1) ke-1 KUHP sebagaimana dalam dakaan Kesatu Penuntut Umum. Terdakwa I dan terdakwa II masing-masing dituntut dengan pidana penjara selama 2 (dua) tahun dan 6 (enam) bulan, sedangkan hakim menjatuhkan pidana penjara selama 1 (satu) tahun 10 (sepuluh) bulan dan denda sebesar Rp 1.000.000.000,- (satu milyar rupiah) dengan ketentuan apabila tidak dibayar dapat diganti dengan pidana kurungan selama 3 (tiga) bulan.

2. Putusan Nomor 12/Pid.Sus/2018/PN. Tjt

Terdakwa I Achmad Saleh Bin Umar Ermulan, terdakwa II Muliadi Sirait Bin Nurdin Sirait (Alm) terbukti secara sah dan meyakinkan bersalah melakukan tindak pidana sebagaimana diatur dan diancam dalam Pasal 16 Ayat (1) Jo Pasal 88 UU RI No. 31 Tahun 2004 tentang Perikanan sebagaimana telah diubah dengan UU RI No. 45 Tahun 2009 tentang Perikanan Jo Pasal 55 Ayat (1) ke-1 KUHP sebagaimana dalam dakaan Kesatu Penuntut Umum. Terdakwa I dan terdakwa II masing-masing dituntut dengan pidana penjara selama 4 (empat) tahun dan 6 (enam) bulan, dan denda sebesar Rp 1.000.000.000,- (satu milyar) kepada masing-masing terdakwa dengan ketentuan apabila tidak dibayar dapat 
diganti dengan pidana kurungan selama 3 (tiga) bulan, Jaksa Penuntut Umum juga mendakwa dengan dakwaan alternatif dengan Pasal 31 Ayat (1) Jo Pasal 9 Ayat (2) Undang-Undang RI No. 16 Tahun 1992 tentang Karantina Hewan dan Tumbuhan, Pasal 55 Ayat (1) ke-1 KUHP dan Undang-Undang Nomor 8 Tahun 1981 tentang Hukum Acara Pidana serta peraturan Perundang-undangan lain yang bersangkutan. Hakim memutuskan terdakwa dengan putusan bebas terhadap terdakwa I dan Terdakwa II, karena hakim beranggapan tidak terbukti secara sah dan meyakinkan bersalah melakukan tindak pidana sebagaimana dalam dakwaan alternatif Kesatu dan Kedua Penuntut Umum.

Penegakan hukum terhadap kasus penyelundupan Baby Lobster di wilayah hukum Polres Tanjung Jabung Timur belum maksimal terlaksana, karena sebagaimana terlihat pada tabel tersebut dari 3 (tiga) kasus hanya 2 (dua) kasus yang dilanjutkan proses di Pengadilan Negeri Tanjung Jabung Timur dengan putusan bebas. Sedangkan keduanya telah melanggar Pasal 88 Jo Pasal 16 Ayat (1) Undang-Undang RI Nomor 31 Tahun 2004 Tentang Perikanan sebagaimana diubah menjadi Undang-Undang RI Nomor 45 tahun 2009 tentang Perikanan Jo Pasal 55 Ayat (1) ke-1 KUHPidana.

\section{B. METODE PENELITIAN}

Artikel ini menggunakan metode yuridis empiris, dimana metode pendekatan empiris adalah penelitian ilmu hukum yang memandang hukum sebagai fakta yang dapat dikonstatasi atau diamati dan bebas nilai dan memiliki ciri-ciri yaitu: membedakan fakta dari norma, gejala hukum harus murni empiris, yaitu fakta sosial, metodologinya metode ilmu-ilmu empiris dan bebas nilai. Secara yuridis empiris penelitian ini mempelajari bagaimana penegakan hukum pidana terhadap penyeludupan Baby Lobster di wilayah hukum Polres Tanjung Jabung Timur.

\section{PEMBAHASAN}

1. Penegakan Hukum Pidana Terhadap Penyelundupan Baby Lobster di Wilayah

\section{Hukum Polres Tanjung Jabung Timur}

Penegakan hukum pidana sebenarnya tidak hanya membicarakan tentang bagaimana cara membuat peraturan hukum itu sendiri melainkan juga membicarakan apa yang dilakukan oleh aparat penegak hukum dalam mengatasi dan mengantisipasi masalah-masalah yang terjadi di masyarakat dalam penegakan hukum tersebut. Hukum adalah alat untuk mengadakan perubahan dalam masyarakat "Law as a tool of social engineering". Dengan fungsi dan peran yang demikian, maka hukum menjadi suatu aspek penting dalam fungsi kontrol pelaksanaan pembangunan.

Penegakan hukum merupakan proses dilakukannya upaya untuk tegaknya atau berfungsinya norma-norma hukum secara nyata sebagai pedoman perilaku atau hubungan-hubungan hukum dalam kehidupan bermasyarakat dan bernegara.

Penegakan hukum tindak pidana yang terkait dengan penyelundupan Baby Lobster akan berjalan dengan efektif apabila aparat penegak hukum dapat bekerja sama secara profesional dalam menegakan hukum. Karena tugas, wewenang, dan tanggung jawab aparat penegak hukum berbeda-beda tetapi saling berkaitan dan tidak dapat dipisahkan. Seperti dalam praktik penegakan hukum, penyidikan yang dilakukan oleh kepolisian, tuntutan oleh jaksa, sampai penjatuhan vonis melalui putusan hakim. 
Itu semua harus dilakukan secara profesional sehingga dapat mewujudkan rasa keadilan.

Kepolisian memiliki peran dalam proses peradilan yaitu berperan dari proses penyidikan hingga proses ke penahanan. Polisi memiliki wewenang untuk menentukan siapa yang patut disidik, ditangkap dan ditahan. Penuntut umum juga baru bisa melaksanakan fungsinya apabila penyerahan hasil dari pemeriksaan dari penyidik telah selesai. Penuntut umum dapat membuat surat dakwaan dari hasil pemeriksaan dari penyidik berdasarkan berita acara pemeriksaan penyidikan. Demikian juga dengan tuntutan yang dapat disesuaikan dengan berita acara dari penyidik Kepolisian.

Tabel. 2

Kasus Tindak Pidana Penyelundupan Baby Lobster di Pengadilan Negeri Tanjung Jabung Timur

\begin{tabular}{|c|c|c|c|c|c|c|}
\hline \multirow[t]{2}{*}{ No } & \multirow[t]{2}{*}{ Tahun } & \multirow[t]{2}{*}{ Jumlah } & \multicolumn{3}{|c|}{ Proses } & \multirow[t]{2}{*}{ Keterangan } \\
\hline & & & Kepolisian & Kejaksaan & PN & \\
\hline 1 & 2018 & 2 & 2 & 2 & 1 & $\begin{array}{l}1 \text { kasus putusan bebas } \\
1 \text { kasus dihentikan }\end{array}$ \\
\hline 2 & 2019 & 1 & 1 & 1 & 1 & Sudah inkrah \\
\hline
\end{tabular}

Kasus penyelundupan Baby Lobster di Kabupaten Tanjung Jabung Timur dari 3 (tiga) kasus selama tahun 2018 sampai 2019 Pengadilan Negeri Tanjung Jabung Timur 1 (satu) kasus dihentikan atau SP3, karena tidak ada alat bukti yang lengkap untuk proses lebih lanjut.

Putusan bebas kasus Nomor 12/Pid.Sus/2018/PN.Tjt dakwaan pertama Pasal 88 Jo Pasal 16 Ayat (1) Undang-Undang Republik Indonesia Nomor 31 Tahun 2004 tentang Perikanan sebagaimana diubah menjadi Undang-Undang RI No. 45 tahun 2009 Tentang Perikanan Jo Pasal 55 Ayat (1) ke-1 KUHPidana. Jaksa Penuntut Umum menuntut terdakwa dengan pidana penjara kepada masing-masing terdakwa dengan pidana penjara selama 4 (empat) tahun dan 6 (enam) bulan dan denda Rp 1.000.000.000,- (satu milyar rupiah), dakwaan alternatif Pasal 31 Ayat (1) UU RI No. 16 Tahun 1992 tentang Karantina Hewan dan Tumbuhan dengan Pasal 9 Ayat (2), Pasal 55 Ayat (1) Ke-1 KUHP dan Undang-Undang Nomor 8 Tahun 1981 Tentang Hukum Acara Pidana, dan hakim menyatakan terdakwa I dan terdakwa II tidak terbukti secara sah dan meyakinkan bersalah melakukan tindak pidana sebagaimana dalam dakwaan alternatif kesatu dan kedua.

Adapun fakta Yuridis dan fakta persidang dalam kasus tersebut adalah sebagai berikut:

1. Fakta Yuridis

Jaksa Penuntut Umum mendakwa terdakwa I dan terdakwa II dengan dakwaan alternatif kesatu dan alternatid ke dua. Altrnatif kesatuan terdakwa bersalaha melakukan tindak pidana sebagaimana diatur dalam Pasal 88 Ayat (1) Undang-Undang RI Nomor 31 Tahun 2004 Tentang Perikanan sebagaimana diubah menjadi UndangUndang RI Nomor 45 tahun 2009 tentang Perikanan Jo Pasal 55 ayat (1) ke-1 KUHPidana, yang unsur-unsurnya:

1. Setiap orang;

2. Yang melakukan, menyuruh melakukan, atau yang turut melakukan; 
3. Dengan sengaja memasukkan, mengeluarkan, mengadakan, mengedarkan, dan/atau memelihara ikan yang merugikan masyarakat, pembudidayaan ikan, sumber daya ikan, dan/atau lingkungan sumber daya ikan ke dalam dan/atau ke luar wilayah pengelolaan perikanan Republik Indonesia.

2. Fakta persidangan

Berdasarkan alat bukti yang terdapat dalam Pasal 184 Kitab Undang-Undang Hukum Acara Pidana (KUHAP), yaitu:

a. Keterangan saksi

b. Keterangan ahli

c. Surat

d. Petunjuk

e. Keterangan terdakwa

Dari fakta yuridis dalam putusan Nomor 12/Pid.Sus/2018/PN.Tjt, yaitu pertimbangan hakim yang didasarkan fakta-fakta yang terungkap di dalam persidangan dan oleh undang-undang ditetapkan sebagai hal yang harus dimuat di dalam putusan. Adapun pertimbangan hakim yang digolongkan sebagai pertimbangan yuridis secara sistematis yaitu dakwaan berdasarkan atas hasil pemeriksaan dalam putusan 12/Pid.Sus/2018/PN.Tjt, Jaksa Penuntut Umum menuntut terdakwa I dan terdakwa II dengan dakwaan alternatif yaitu melanggar Pasal 31 Ayat (1) Jo Pasal 9 Ayat (2) Undang-Undang RI Nomor 16 Tahun 1992 Tentang Karantina Hewan dan Tumbuhan Jo Pasal 55 Ayat (1) ke-1 KUHPidana.

Apabila dilihat dari unsur-unsur pasalnya telah sesuai karena telah memenuhi unsur-unsur yang terdapat dalam Pasal 31 Ayat (1) Undang-Undang RI Nomor 16 Tahun 1992 Tentang Karantina Hewan dan Tumbuhan.

Sedangkan dalam fakta persidangan yang terungkap di persidangan terdapat kesesuaian antara keterangan terdakwa, keterangan saksi dan juga alat bukti yang terungkap di persidangan sehingga perkara tersebut telah terbukti secara sah dan meyakinkan telah melakukan tindak pidana penganiayaan karena tidak ditemukan alasan pemaaf dan pembenar, sehingga terhadap perkara ini dapat dijatuhi pidana.

Pada umumnya masalah penegakan hukum pidana dimulai pada satu titik, yaitu terjadinya pelanggaran hukum pidana dan kejahatan yang dalam hal ini terkait dengan tinak pidana penyelundupan Baby Lobster. Dari permasalahan ini kemudian dapat dimulai dengan memahami dan melaksanakan penegakan hukum tersebut mulai dari orang pribadi sebagai anggota masyarakat yang mengetahui terjadinya pelanggaran dan kejahatan baik tanpa adanya laporan atau pengaduan dan penegak hukum yang menangani pemberantasan baik kejahatan maupun pelanggaran yang terjadi.

Masalah utama penegak hukum khususnya Indonesia bukanlah pada sistem hukum itu sendiri, melainkankan pada kualitas manusia yang menjalankan hukum. Dengan demikian peranan manusia yang menjalankan hukum itu menepati posisi strategis. Masalah transparasi penegak hukum berkaitan erat dengan akuntabilitas kinerja lembaga penegak hukum.

Penegakan hukum harusnya dilandasi dengan etika dan moral sehingga terjadi sinkronisasi antara sisi keadilan dan juga sisi kepastian hukum. Tidak boleh ada upaya 
penegakan hukum pidana yang hanya mengedepankan sisi kepastian hukum saja, dengan mengesampingkan sisi keadilannya dan begitu pula sebaliknya. ${ }^{10}$

Namun sebagaimana yang telah kita ketahui bahwa salah satu penyebab lemahnya penegak hukum di Indonesia, hal ini terbukti dengan masih ada kasus tindak pidana yang tidak dapat dilanjutkan ke tingkat Pengadilan atau dihentikan (SP3). Beberapa permasalahan tentang penegakan hukum tidak dapat terlepas dari kenyataan bahwa fungsi hukum sangatlah tergantung pada hubungan yang serasi antara hukum itu sendiri, aparat penegak hukum, fasilitas dan masyarakat yang di aturnya.

Penyelundupan Baby Lobster di wilayah hukum Polres Tanjung Jabung Timur akan berdampak dengan produksi Lobster dan akan mempengaruhi penghasilan petani nelayan Lobster khususnya. Oleh karena itu penegakan hukum pidana terhadap pelaku penyelundupan Baby Lobster di wilayah hukum Polres Tanjung Jabung Timur harus dilakukan secara maksimal dan terpadu antara aparat penegak hukum.

Untuk mengetahui lebih lanjut bagaimana penegakan hukum pidana penyelundupan Baby Lobster sebagaimana disebutkan dalam Pasal 16 Ayat (1) Undang-Undang Nomor 45 Tahun 2009 terhadap penyelundupan Baby Lobster di Kabupaten Tanjung Jabung Timur, dalam pembahasan permasalahan penegakan hukum ini akan merujuk pada teori Soerjono Soekanto mengenai faktor-faktor yang mempengaruhi penegakan hukum.

1. Faktor hukumnya sendiri

Faktor hukumnya sendiri dari suatu penegakan hukum berupa peraturan perundang-undangan yang terkait terhadap tindak pidana tersebut. Penegakan hukum pidana maka peraturan perundang-undangan yang terkait terhadap tindak pidana penyelundupan Baby Lobster sebagaimana diatur dalam Undang-Undang Nomor 45 Tahun 2009 Perubahan atas Undang-Undang Nomor 31 tahun 2004 tentang Perikanan.

"Terkait tindak pidana penyelundupan Baby Lobster pelaku diancam dengan pidana 6 (enam) tahun dan denda Rp 1.500.000.000,- (satu milyar lima ratus juta rupiah), sedangkan kasus penyelundupan Baby Lobster ditahun 2018 dan tahun 2019 2 (dua) kasus tidak dilanjutkan ke tingkat Kejaksaan Negeri Tanjung Jabung Timur dan 1 (satu) kasus yang sudah diputuskan. Tidak dilanjutkan kasus penyelundupan di tahun 2018 adalah disebabkan karena tidak adanya alat bukti yang lengkap"11.

\section{Faktor penegak hukum}

Penegak hukum merupakan golongan panutan dalam masyarakat, yang mempunyai kemampuan tertentu, sesuai dengan aspirasi masyarakat. Secara sosiologis, setiap penegakan hukum tersebut mempunyai kedudukan (status) dan peranan (role). Kedudukan (sosial) merupakan posisi tertentu di dalam struktur kemasyarakatan, yang mungkin tinggi, sedang-sedang saja atau rendah. Kedudukan tersebut sebenarnya merupakan suatu wadah, yang isinya adalah hak-hak dan kewajiban-kewajiban tertentu.

Penegak hukum merupakan golongan panutan dalam masyarakat, yang hendaknya mempunyai kemampuan-kemampuan tertentu, sesuai dengan aspirasi

10 Sri Dewi Rahayu, Yulia Monita, "Pertimbangan Hakim Dalam Putusan Perkara Tindak Pidana Narkotika", PAMPAS: Journal Of Criminal Law, Vol. 1, No. 1 (2000), hlm. 127. https://onlinejournal.unja.ac.id/Pampas/article/view

11 Wawancara dengan Sujudi, Kepala Kanit Reserse Kriminal Khusus Polresta Tanjung Jabung Timur, Tanggal 6 Januari 2020 
masyarakat. Mereka harus dapat berkomunikasi dan mendapatkan pengertian dari golongan sasaran, disamping mampu membawakan atau menjalankan peranan yang dapat diterima oleh mereka. Kecuali dari itu, maka golongan panutan harus dapat memanfaatkan unsur-unsur pola tradisional tertentu, sehingga menggairahkan partisipasi dari golongan sasaran atau masyarakat luas. Golongan panutan juga harus dapat memilih waktu dan lingkungan yang tepat di dalam memperkenalkan normanorma atau kaidah-kaidah hukum yang baru, serta memberikan keteladan yang baik.

3. Faktor sarana atau fasilitas

Faktor sarana dan fasilitas yang lengkap ikut menentukan dalam penegakan hukum. Faktor ini menjadi salah satu faktor yang memperlancar proses penegakan hukum, sarana atau fasilitas adalah berpengaruh dalam penanganan suatu perkara, yang salah satunya adalah perkara tindak pidana penyelundupan Baby Lobster di wilayah hukum Tanjung Jabung Timur. Proses penegakan hukum yang dimulai dari penyelesaian perkara pidana penyelundupan Baby Lobster di mulai dari tingakat kepolisian, kejaksaan, pengadilan. Tanpa adanya sarana atau fasilitas tersebut, tidak akan mungkin penegak hukum menyerasikan peranan yang seharusnya dengan peranan yang aktual.

4. Faktor Masyarakat

Faktor penegakan hukum yang berasal dari masyarakat bertujuan untuk mencapai kedamaian dalam masyarakat. Oleh karena itu, dipandang dari sudut tertentu maka masyarakat dapat mempengaruhi penegakan hukum tersebut. Mengenai masyarakat maka hal ini sedikit banyaknya menyangkut masalah derajat kepatuhan. Secara sempit dapat dikatakan bahwa derajat kepatuhan masyarakat terhadap hukum merupakan salah satu indikator berfungsinya hukum yang bersangkutan.

Penegakan hukum pidana dilakukan dengan tujuan untuk menciptkan keamanan, ketentraman, kedamaian dan kenyamanan hidup dimasyarakat. Dengan demikian maka, masyarakat memiliki pengaruh dalam pelaksanaan penegakan hukum. Masyarakat di Kabupaten Tanjung Jabung Timur tidak semuanya paham akan hukum.

Paradigma yang digunakan oleh masyarakat untuk taat pada hukum adalah obyek sanksinya. Masyarakat akan menilai hukum dari sanksi yang diberikan jika melanggar. Faktor sanksi ini sangat berpengaruh pada bagaimana tingkat kesadaran seseorang untuk patuh pada hukum.

5. Faktor Kebudayaan

Faktor kebudayaan, faktor ini tidak bisa dilepaskan dengan masyarakat, karena di dalam masalah sistem nilai-nilai yang menjadi inti dari kebudayaan. Sebagai suatu sistem (atau subsistem dari sistem kemasyarakatan), maka hukum mencakup, struktur, substansi, dan kebudayaan.

Kebudayaan (sistem) hukum pada dasarnya mencakup nilai-nilai yang mendasari hukum yang berlaku, nilai-nilai yang merupakan konsepsi-konsepsi abstrak mengenai apa yang dianggap baik (sehingga dianut) dan apa yang dianggap buruk sehingga dapat dihindari.

\section{Kendala penegakan hukum Hukum Pidana Terhadap Penyelundupan Baby Lobster di Wilayah Hukum Polres Tanjung Jabung Timur.}

1) Sumber daya manusia

Sumber daya manusia dalam hal ini pihak kepolisian tidak semuamya memahami mengenai tindak pidana penyelundupan. Hal ini menyebabkan aparat penegak hukum 
yang digerakkan terbatas pada mereka yang mengerti mengenai tindak pidana perikanan.

Dengan jumlah personel kepolisian yang terbatas sehingga penegakan hukum di Tanjung Jabung Timur tidak efesien dan tidak efektif.

2) Kendala pada faktor masyarakat

Adanya kecendrungan masyarakat yang tidak menyadari bahwa hak-hak mereka telah dilanggar yang tidak mengetahui bahwa mereka dapat melindungi kepentingankepentingan mereka melalui upaya hukum serta banyak juga yang tidak melaporkan tindak pidana penangkapan dan menjual Baby Lobster secara ileggal karena disebabkan oleh faktor-faktor keuangan atau sosial.

Masyarakat yang kebanyakan tidak ingin ikut terlibat permasalahan hukum, karena apabila mereka melaporkan suatu permasalahan yang terjadi disekitar lingkungannya, maka pada umumnya masyarakat seolah-olah tutup mata dengan permasalahan tersebut. Masyarakat tidak ada yang berinisiatif untuk melapor kepada pihak yang berwajib. Dengan sikap masyarakat seperti itu yang tidak peduli dengan lingkungannya tersebut, masyarakat yang tidak mau membantu pihak kepolisian dalam mencari alat bukti dan bersedia menjadi saksi dalam suatu perkara yang mereka ketahui, membuat aparat penegak hukum itu sendiri tidak bisa bekerja dengan cepat.

3) Kendala Sarana dan Prasarana

Pada faktor sarana dan prasarana ini, untuk melakukan penegakan hukum pidana yang melanggar Pasal 16 Ayat (1) Undang-Undang Nomor 45 Tahun 2009 Tentang Perikanan, pada tahap penyelidikan dan penyidikan, terdapat beberapa masalah yaitu tanpa adanya sarana atau fasilitas tertentu, maka tidak mungkin penegakan hukum itu sendiri akan berjalan dengan baik dan lancar. Sarana atau fasilitas tersebut antara lain, mencakup peralatan yang memadai, keuangan yang cukup, dan lain sebagainya. Kurangnya dana penyidik dalam melakukan penyidikan terhadap kasus penggelapan Baby Lobster di Kabupaten Tanjung Jabung Timur juga menyebabkan penegakan hukum pidana itu sendiri tidak bisa berjalan dengan baik dan lancar.

\section{SIMPULAN}

Artikel ini menyimpulkan pertama, Penegakan hukum pidana Penyelundupan Baby Lobster di Wilayah Hukum Polres Tanjung Jabung Timur belum terlaksana dengan efektif, yang mana kasus penyelundupan Baby Lobster 3 (tiga) kasus dari tahun 2018 sampai 2019 hanya 2 (dua) kasus yang diproses sampai ke Pengadilan, sedangkan 1 (satu) kasus pada tahun 2018 tidak dilanjutkan atau dihentikan karena tidak adanya bukti yang lengkap. Sedangkan satu kasus yang diputus bebas oleh Pengadilan Negeri Tanjung Jabung Timur yaitu hakim beranggapan bahwa unsur ke-2 maupun ke-3 dari pasal pada dakwaan Alternatif kedua tidaklah terpenuhi secara sah dan meyakinkan. Penegakan hukum masih belum maksimal karena keterpaduan dan koordinasi antar aparat penegakan hukum serta partisipasi masyarakat untuk ikut berperan dalam pelaksanaan penegakan hukum masih kurang. Kedua, kendala dalam penegakan hukum pidana penyelundupan Baby Lobster di Wilayah Hukum Polres Tanjung Jabung Timur terhadap pelaku, antara lain kendala pada faktor sarana dan prasaranannya dan sumber daya manusia personil penyidik yang kurang banyak, dana yang terbatas dan kendala pada faktor masyarakat yaitu kurangnya kesadaran hukum. 


\section{DAFTAR PUSTAKA}

\section{Dokumen Hukum}

Repubik Indonesia. Undang-Undang Dasar Negara Tahun 1945.

Republik Indonesia. Peraturan Menteri Kelautan dan Perikanan Nomor 56/Permen$\mathrm{KP} / 2016$.

Republik Indonesia. Undang-Undang Nomor 16 Tahun 2006 Tentang Karantina Hewan, Ikan dan Tumbuhan.

Republik Indonesia. Undang-Undang Nomor 31 Tahun 2004 Tentang Perikanan.

\section{Buku}

Anwar, Mochammad. Segi-Segi Hukum Masalah Penyelundupan. Bandung: Alumni, 2001.

Asikin, H. Zainal dan Amiruddin. Pengantar Metode Penelitian Hukum. Jakarta: PT RajaGrafindo Persada, 2006.

Hadikusuma, Hilman. Bahasa hukum indonesia. Bandung, 1992.

Hamidjojo, Noto. Soal-Soal Pokok Filsafat Hukum. Salatiga: Griya Media, 2011.

Hamzah, Andi. Asas-Asas Hukum Pidana. Jakarta: Edisi Revisi. Rieneka Cipta, 2010.

Hamzah, Andi. Bunga Rampai Hukum Pidana dan Acara Pidana. Jakarta: Ghalia Indonesia, 2001.

Harun M.Husen, Harun. Kejahatan dan Penegakan Hukum Di Indonesia. Jakarta: Rineka Cipta, 1990.

Lopa, Baharudin. Tindak Pidana Ekonomi. Jakarta: Penerbit PT. Pratnya Paramita, 2002.

Mertokusumo, Sudikno. Teori Hukum. Jakarta: Cahaya Atma Pustaka, 2012.

Moeljatno. Asas-asas Hukum Pidana. Surabaya: Putra Harsa, 1993.

Nasution, Bahder Johan. Metode Penelitian Ilmu Hukum. Bandung: Mandar Maju, 2008.

Nawawi Arief, Barda dan Muladi. Teori-Teori dan Kebijakan Pidana. Bandung: Alumni, 2005.

Prasetyo, Teguh. Hukum Pidana, Jakarta: Rajawali Press, 2010.

Rahardjo, Satjipto. Bunga Rampai Permasalahan dalam Sistem Peradilan Pidana. Jakarta: Pusat Pelayanan Keadilan dan Pengabdian Hukum, 1998.

Rifai, Ahmad. Penemuan Hukum Oleh Hakim Dalam Perspektif Hukum Progresif. Jakarta: Sinar Grafika , 2011. 
Soekanto, Soerjono. Faktor-faktor Yang Mempengaruhi Penegakan Hukum. Jakarta: UI Pres, 2014.

Soema Dipradja, Achmad. Asas-asas Hukum Pidana. Bandung: Alumni, 1982.

Sudarto. Hukum Pidana I. Semarang: Yayasan Sudarto, 1990.

Jurnal

Al Arif, M. Yasin, "Penegakan Hukum Dalam Perspektif Hukum Progresif", Undang Jurnal Hukum, Vol. 2, No. 1 (2019).

Nababan, Monika Dwi Putri, Kabib Nawawi, "Pelaksanaan Hak Tahanan (Tantangan dan Permasalahan). PAMPAS: Journal of Criminal Law, Vol. 1, No. 1 (2020).

Rahayu, Sri Dewi, Yulia Monita, "Pertimbangan Hakim Dalam Putusan Perkara Tindak Pidana Narkotika”, PAMPAS: Journal OfCriminal Law, Vol. 1, No. 1 (2000).

\section{Internet}

https://kkbi.web.id/.lobster. Diakses tanggal 23 Oktober 2019 pukul 15.00 Wib

https://id.wikipedia.org/wiki/Penyelundupan.pengertian+penyelundupan, diakses tanggal 29 Desember 2019, pukul 21.35 WIB 